\title{
Diskirminasi Kaum Muslim Di India Menurut Konvensi Hak Asasi Manusia
}

\author{
R. Yahdi Ramadani \\ S1 Ilmu Hukum Universitas Trunojoyo Madura \\ r.yahdi.ramadani@gmail.com
}

\begin{abstract}
Abstraksi
Human rights problems can arise because discussing a country is incapable of doing something or actively doing something. Muslim people in India spend discrimination which begins with the passage of a new amendment citizenship law, while the rights of Muslims recognized by India are restored, making it recognized by the law of completion by India where India itself has actually ratified human rights. international conventions of civil and political rights and other international conventions related to the protection and security of each individualKeywords: Discrimination, Indian Muslims, Citizenship Law
\end{abstract}

\begin{abstract}
Abstraksi
Permasalahan hak asasi manusia dapat muncul dikarnakan apabila suatu negara tidak mampun bebuat sesuatu atapun aktif berbuat sesuatu. Orang yang beragama muslim di india mengalami deskriminasi yang berawal dari penerbitan Undang-undang kewarganegaraan yang baru di amandemen dimana hak orang muslim yang seharusnya di akui oleh india keberadaannya kini tidak di akui dengan penerbitan undang-undang tersebut sehingga permasalahan ini menjadi cukup rumit yang harus di selesaikan oleh india dimana india sendiri sejatinya sudah meratifikasi hak asasi manusia yaitu konvensi internasional hak sipil dan politik dan konvensi internasonal lain yang berhubungan dengan perlindungan dan menjamin kemanan bagi setiap individu ataupun kelompok.
\end{abstract}

Kata kunci: Diskriminasi, Muslim India, Undang-undang Kewarganegaraan 


\section{Latar Belakang}

Hak yang melekat secara alamiah (inheren) mulai dari manusia lahir dan tumbuh manusia mempunyai hak dan tanpa hak tidak dapat tumbuh dan berkembang sebagai manusia yang utuh inilah yang sering di kenal dengan Hak Asasi Manusia. Hak asasi manusia pada di zaman globalisasi saat ini begitu penting karna dapat mengkontrol manusia untuk mengembangkan bakat bakat dan memenuhi kebutuhan kebutuhannya manusia untuk hidup sehingga kehidupanya tidak mengalami suatu tekanan, tanpa hak asasi manusia menimbulkan kejadian sebaliknya. Prinsip Non-diskriminasi, Prinsip universal, Prinsip Saling bergantung, Prinsip tak terbagi, Prinsip Saling terkait, Prinsip Martabat manusia, Prinsip Kesetaraan dan Prinsip Tanggung jawab negara adalah Prinsip-prinsip hak asasi manusia yang perlu di ketahui, dari beberapa prinsip-prinsip tersebut hak-hak dasar harusnya di akui secara utuh oleh suatu negara (Riyadi, 2018:26)

$$
\text { Kodratnya merupakan }
$$

merupakan hak sebagai bagian dari kemanusiaan atau hakikat dan prinsip universal, prinsip ini menjadi hak asasi manusia pada yang diakui secara universal sebagai hak-hak yang melekat pada manusia atau sering di sebut Hak-hak mendasar fundamental.Hak asasi ini bersifat melekat yang bermakna hak-hak tersebut tidak dapat dirampas atau dicabut oleh suatu organisasi ataupun suatu negara dimana setiap sosok manusia apapun warna kulit jenis kelamin usia latar belakang budaya agama atau kepercayaannya sementara dikatakan melekat atau inheren karena itu memiliki setiap manusia semata-mata karena keberadaannya sebagai manusia dan bukan karena pemberian dari suatu organisasi kekuasaan manapun (Riyadi, 2018:9)

Keberadaan kaidah-kaidah hak asasi manusia sebagai manusia dapat memahami bahwa hal ini merupakan hasil dari sebuah pengembangan pemikiran dan berbagai upaya menciptakan kehidupan dan tata dunia yang lebih terhormat selama berabad-abad hal ini dijelaskan berdasarkan konsep hak asasi manusia yang muncul dan 
berkembang di kejayaan islam dengan di tanda tangani piagam Madinah sebagai dasar-dasar konstitusi yang mencantukan hak asasi manusia lalu mulailah berkembang di Eropa Barat sejak abad pertengahan sebenarnya tumbuh bersamaan dengan muncul dengan paham kebangsaan yang mengilhami lahirnya negara-negara modern dan sekuler. Gagasan ini dimunculkan sebagai alternatif perombakan atau sistem politik dan ketatanegaraan sentralistik dimana kekuasaan negara terletak di tangan penguasa secara absolut atau sering dikatakan kaku. Absolutisme ini sendiri sering di artikan mengenai kekuasaan yang terlihat kaku dimana kekuasaan dapat menimbulkan konflik antara Penguasa dan rakyat atau antara Kekuasaan pemerintahan dan kebebasan warga negara hal ini sering terjadi karna kurang di akuinya konsep hak asasi manusia secara specific. (Sujatmoko, 2015:28)

Tindakan sewenang-wenang dari pihak yang berkuasa terhadap individu ada beberapa factor yang dikatakan sebagai benang merah hak asasi manusia dan pada hakikatnya nya individu sebagai manusia memiliki hak asasi manusia, Secara filosofis hak asasi manusia untuk melindungi individu sebagai manusia dari pihak yang berkuasa. Dapat di ketahui bahawasanya penguasa adalah pihak yang memiliki kekuatan dan kewenangan yang lebih dibandingkan dengan individu pada umumnya di mana suatu konsekuensi logis Mengapa kewajiban untuk melindungi hak asasi manusia dibebankan kepada penguasa yaitu antara lain negara pemerintahan atau Aparatur Negara karna sering terjadinya pelanggaran hak asasi manusia pada rakyatnya yang menjadikan sutu kebijakan terkadang merugikan kelompok ataupun individu tertentu. (Sujatmoko, 2015:29)

Sering sekali apabila membahas persoalan hak asasi manusia maka akan membahas juga menganai pelanggaran hak asasi manusia pada hakekatnya merupakan kejahatan luar biasa di mana aspek Luar biasa ini diindikasikan dengan adanya penyalahgunaan kekuasaan yang menyertai kejahatan tersebut 
hal ini dapat terjadi terutama apabila dilakukan oleh mereka termasuk sebagai Aparatur Negara yang memiliki kewenangan tertentu Namun dapat juga terjadi walaupun pelaku bukan Aparatur Negara tetapi sipelakku bertindak atas nama negara. Pada hakikatnya pelanggaran hak asasi manusia mempunyai kekusa khusus yaitu adanya penyalahgunaan kekuasaan abuse of power yang artinya para pelaku bertindak dalam konteks pemerintahan dan difasilitasi oleh kekuasaan pemerintahan komitmen governmental konteks and by government power.

Hak asasi manusia dapat dikatakan menjadi dasar apabila setiap individu di jamin hak-hak dan kewajibannya dari permasalah pelanggaran hak asasi manusia yang berkaitan dengan kewajiban negara atau pihak-pihak yang secara hukum berkewajiban untuk melindungi dan menghormati norma-norma hak asasi manusia internasional. Namun menyatakan bahwa yang dimaksud dengan pelanggaran hak asasi manusia merupakan pelanggaran terhadap suatu norma ham atau perjanjian internasional hak asasi manusia yaitu kegagalan dari negara atau pihak yang secara hukum diwajibkan untuk mematuhi normanorma hak asasi manusia internasional. Hal ini yang menjelaskan bahwa menggunakan hak asasi manusia sesuai dengan hukum yang berlaku demi eksistensi jaminan pelanggan pengakuan dan penghormatan terhadap hak-hak dan kebebasan orang lain dengan demikian dapat disimpulkan bahwa pelanggaran HAM akan timbul atau terjadi apabila negara tidak berbuat sesuatu untuk mencegah terjadinya tindak pidana tersebut sehingga yang terjadi adalah pelanggaran HAM. (Sujatmoko, 2015:31)

Individu maupun kelompok yang Bergama islam dilematis yang berkepanjangan sering diperlakuan diskriminatif di berbagai negara, hal ini menjadi suatu permasalahan yang berkepajangan contohnya diskriminasi terhadap umat Islam minoritas di india mengalami diksriminasi berkepanjangan. (Mubasirun, 2015:10) Muslim wajib terikat pada aturan-aturan Allah di manapun mereka berada hal ini 
menjadi permasalahan karna keagaaman mayoritas menekan dan mendekriminasi agama minoritas, dapat dilihat terbitnya Undangundang Kewarganegaraan yang mengandung diskriminasi kepada umat muslim.

Dalam Undang-undang Kewarganegaraan yang baru, tercatat akan mempercepat pemberian kewarganegaraan untuk warga dari enam agama: Hindu, Sikh, Buddha, Jain, Parsi, dan Kristen yang berasal dari negara tetangga Afghanistan, Bangladesh dan Pakistan, jika mereka datang ke India sebelum 2015 sehingga Undang-undang an Kewarganegaraan ini merupakan sebuah ancaman pada golongan kelompok beragama muslim yang tidak termasuk dalam agama tersebut. Hal inilah yang menyulut protes warga India hal ini menjadi Isu hukum Hak Asasi Manusia dimana golongan kelompok beragama muslim membutuhkan perlindungan hal ini di atur dalam deklarasi intrenasional atau konvensi internasional.Sebelum diamandemen, isi Undang-undang Kewarganegaraan Amandemen
Kewarganegaraan melarang imigran ilegal menjadi warga negara India. Di bawah Undang-undang Kewarganegaraan lama, siapapun yang dianggap imigran ilegal bisa dideportasi atau dipenjara. (Suci Agiesta, 2020:1)

\section{Pembahasan}

$$
\text { Beberapa yang terjadi }
$$
mengenai diskriminasi oleh penguasa di india terhadap kelompok minoritas yaitu khusus umat muslim menjadi semakin bersifat diskriminatif , utamanya permasalahan di India mengenai Hak Asasi Manusia di india ini muncul di dasarkan pada Undang-undang Kewarganegaraan 1955 pertama kali muncul di Parlemen pada Juli 2016 kemudian Undang-undang Kewarganegaraan 1955 di amandemen dan menjadikan agama sebagai dasar kewarganegaraan. Permasalahan dalam dasar hukum tentang kewarganegaraan di india ini menjadi permasalahan adanya deskiminasi pada kelompok tertentu dimana agama sebagai kriteria kelayakan untuk menjadi warga negara jelas hal ini negara membatasi Hak Asasi Manusia di sini , Undang-undang 
kewarganegaraan ini mendapat Presiden India Ram Nath Kovind pada 12 Desember 2019, adapun berikut isi Undang-undang yang telah di Amandemen yang berbau dekriminasi pada kaum muslim di india : "In the Citizenship Act, 1955 (hereinafter referred to as the principal Act), in section 2, in subsection (1), in clause (b), the following proviso shalla be instered namely : "Provided that any person belonging to Hindu, Sikh, Buddhist, Jain, Parsi or Christian community from Afghanistan, Bangladesh or Pakistan, who entered into India on or before the 31st day of December, 2014 and who has been exempted by the Central Government by or under clause (c) of sub-section (2) of section 3 of the Passport (Entry into India) Act, 1920 or from the application of the provisions of the Foreigners Act, 1946 or any rule or order made thereunder, shall not be treated as illegal migrant for the purposes of this Act;".(Sinintya Mangkuto, 2019:2)

Dalam undang-undang kewarganegaraan ini tersebut menyebutkan berbagai agama teapi agama Islam tidak di sebut sedangkan tidak dapat di pungkiri bahwa orang yang memeluknya agama muslim sekitar $14 \%$ nya dari 1,3 miliar orang India beragama Hindu yang dominan lalu, sisanya adalah Kristen, Budha, dan lainnya. Undang-undang Kewarganegaraan ini menimbulkan presepsi mengenai perbedaan perlakukan terhadap pemeluk agama islam sebagai agama minoritas di India sehingga dapat dilihat dari beberapa aspek secara hukum internasional apakah hal ini termasuk dalam pelanggaran hak asasi manusia oleh india sebagai negara yang seharusnya mempunyai tanggung jawab untuk melindungi dan menjamin hak asasi manusia.

\section{Berdasarkan Deklarasi Universal Hak Asasi Manusia}

Setiap individu ataupun kelompok berhak atas kebebasan pikiran hati nurani dan agama termasuk kebebasan berganti agama atau kepercayaan dan kebebasan untuk menyatakan agama atau kepercayaan dengan cara 
mengajarkan

mempraktikkan

melaksanakan ibadah hal ini juga kan berhubungan dengan tingkatan mentaatinya baik sendiri maupun bersama-sama dengan orang lain di muka umum maupun sendiri ini lah gambaran dasar mengenai agama yang harus diakui oleh suatu negara apabila individu mempunyai sautu kepercayaan. Hal ini menjadi analisis awal dari kasus India tersebut bahwa setiap orang baik beragama apapun tersebut memiliki hak untuk menyatakan ke agamaannya hal ini sejalan dengan pengertian fundamental dari hak asasi manusia yang di akui secara universal termasuk di situ mengenai hakikat dan kodratnya manusia hak-hak agama yang ini bersifat melekat maka hak-hak tersebut juga tidak dapat dirampas atau dicabut hal ini telah jelas di akui oleh Hukum Internasional dalam pengaturan beberapa Konvensi internasional yang mengatur tentang hak asasi manusia bukan hanya deklarasi universal hak asasi manusia saja begitu pula pada negara-negara yang meratifikasi konvensi mengenai hak asasi manusia .(Pasal 18 Deklarasi Universal Hak Asasi Manusia)

Setiap orang memiliki hak pengakuan yang sama, sebagai pribadi, di hadapan hukum hal ini menjelaskan mengenia Kesetaraan dimaknai sebagai perlakuan yang setara dimana pada situasi yang sama harus diperlakukan dengan sama dan dimana pada situasi berbeda dengan sedikit perdebatan diperlakukan secara berbeda. Artinya jika di kaitkan dalam kasus ini maka muslim india seharusnya secara prinsip harus di akui di hadapan hukum dikanrkan penduduk muslim di india yang sedikitnya mencapai $12 \%$ ini pada dasarnya harus di akui hal ini agar implementasi dari Duham ini berjalan dengan sebagaimaana mestinya. dan Setiap orang memiliki hak yang sama di hadapan hukum dan berhak atas perlindungan hukum tanpa adanya diskrirninasi pada konsep ini juga perlu di perhatikan, jenis diskriminasi yang sering terjadi di masyarakat antara lain tapi tidak terbatas pada: 1. Discrimination based on sex and gender (social roles due to sex)2. Discrimination 
based on ethnicity / ethnicity, race, and religion / belief. 3 . Discrimination against persons with disabilities. 4. Discrimination due to social caste 5. Discrimination in sufferers of the disease. (Fulthoni, 2009:6)

Pada kasus muslim di india ini termasuk dalam diskriminasi berdasarkan agama dimana agama menjadi tolak ukur pengakuan suatu kelompok masyarakat dan berkumpul hal ini dapat dilihat muslim di india mendapatkan diskriminasi yang mengalami pengurangan, penyimpangan atau penghapusan pengakuan, pelaksanaan atau pemenuhan hakhak dasarnya sebagai manusia. Seharusnya perlakuan terhadap kaum muslim di india ini di jaga martabatnya (dignity), walaupun bagaiman manapun manusia tetap membutuhkan suatu perlindungan.

\section{Berdasarkan Konvensi Internasional Tentang Hak Sipil Dan Politik ( ICCPR )}

Konsep hak asasi manusia internasional yang hanya mengenal satu bentuk kewajiban bagi individu dan atau kelompok yaitu menghormati hak asasi manusia sehingga individu dan atau kelompok tidak mempunyai kewajiban memenuhi. melindungi kondisi ini didasarkan pada resolusi majelis umum 53/144 pada 9 Desember 1948 yang berbunyi recognize the rights and responsibilities of individual groups and associations to advance respect and strengthen knowledge about human rights and basic freedoms at the national and international level. Dalam permasalahan dewasa ini kita dapat melihat bahwa India meratifikasi ICCPR 10 april 1979 dalam hukum nasionalnya dan seharus india dapat meng implementasikan konsep konvensi ini dalam pengakuan terhadap kelompok umat muslim india (Riyadi, 2018:85)

Prinsip non diskriminasi yang banyak di ketahu oleh masyarakat internasional pada umumnya hal ini tercantum konvensi ini dapat dimaknai bahwa semua hak-hak yang di miliki suatu individu ataupun kelompok yang ada dalam konvenan ini sendiri berlaku bagi semua orang 
tanpa dipengaruhi oleh perbedaan antas dasar apapun seperti ras warna kulit jenis kelamin bahasa agama politik dan lainnya hal ini dikankan akan sangat berpengaruh pada tingkatan diskriminasi pada individu ataupun kelompok tersebut apabila tidak di jamin oleh penguasa atapun negara dan konvensi ini juga meminta agar para pihak berjanji untuk menjamin hak yang sederajat antara laki-laki dan perempuan untuk menikmati seluruh kategori hak sipil dan politik. Beberapa penjelasan mengenai Prinsip dari Konvensi Internasional Tentang Hak Sipil Dan Politik ini menjelaskan bahwa tanggung jawab negara atau sering dikenal dengan State Responsibility dimaknai bahwa penghormatan atas seluruh hak sipil dan politik adalah menjadi tanggung jawab negara.

Prinsip prinsip hak asasi manusia dalam arti tanggung jawab negara berdasarkan pasal 2 Konvensi Konvensi Internasional Tentang Hak Sipil Dan Politik yang berbunyi : Each party to the convention promises to respect and guarantee the rights recognized in this convention for all people in its territory and to submit to its jurisdiction without differentiating anything such as race, color, sex, religion, political language and other opinions about origin. nationality or social wealth give birth or other status, In the case that it has not been regulated in statutory provisions or other policies in each of the parties to the promised convention to take the necessary steps in accordance with the constitutional process and with the provisions of the provisions in this case the convention to establish statutory provisions other invitations or policies needed to enforce the rights recognized in this convention. (Pasal 2 Konvensi Internasional Tentang Hak Sipil Dan Politik)

Sehingga dapat di analsisi apabila di hubungkan dengan permasalahan hak asasi manusia di india, India yang telah meratifikasi konvensi ini seharusnya mengingat akan janji untuk menghormati dan menjamin hak-hak umat muslim di india yang jelas-jelas diakui dalam konvensi ini di dalam wilayah dan tunduk pada wilayah hukumnya tanpa membedakan apapun seperti 
ras warna kulit jenis kelamin agama bahasa politik maka dari sinilah harusnya india meng aplikasikan konvensi ini sebgai tolak ukur perlindungan hak asasi manusia karna pada dasarnya yang dapat melindungi ham tetap terjaga adalah negara itu sendiri.Selain itu jaminan terhadap hak atau kebebasan yang sebagaimana diakui dalam konvensi dengan ini dilanggar akan mendapat pemulihan yang efektif meskipun pelanggar ini dilakukan oleh orang yang bertindak dan kapasitas resmi dan harusnya penerbitan Undangundanng kewarganegaraan itu harusnya menjamin bahwa pejabat yang berwenang india membuat suatu aturan hukum untk menjamin perlindungan bukan membatasi yang jelas-jelas kaum muslim di india adalah warga negaranya yang harus di lindungi dan di berikan akui secara hukum bukan untuk di siksa serta di intimidasi

\section{Pelanggaran Hak Asasi Manusia}

Upaya yang di lakukan oleh pemerintah india ini menimbulkan aksi dari kelompok muslim india ini yang merasa haknya di ambil dan timbulnya tidak diaki agama islam di india beberapa kali aksi penolakan Undang undang Kewarganegaraan menimbulkan korban karna masyarakat agama lain ikut campur dalam aksi protes tersebut bahkan tindakan diskriminatif terhadap wkaum muslim juga dilakukan oleh agama minoritas di india. Dari jumlah orang terluka di data sebanyak 100 orang terluka dan menelan korban yang cukup banyak yang mencapai 42 Orang. Kekerasan itu Apabila dilihat dari kasus India permaslahan Hak Asasi dapat berpotensi melakukan pelanggaran hak asasi manusia. (Siddiqui, 2020:2)

Pelanggaran HAM hanya dapat dilihat dengan pembagian kewajiban negara itu dua bentuk pelanggaran hak asasi manusia secara pasif dan pelanggaran secara aktif yaitu: Pelanggaran yang terjadi akibat negara yang harusnya melaksanakan kewajibannya melindungi hak asasi manusia yang di akui oleh seluruh negara di dunia namun negara tersebut tidak melakukan tindakan apa-apa hal ini sering di sebut dengan pelanggaran 
hak asasi manusia secara pasif sedangkan secara aktif pelanggaran yang terjadi akibat negara seharusnya tidak berperan apa-apa atau diam dan menghormati hak asasi manusia namun negara tersebut aktif atau betindak sewenang-wenang bahkan menjadi pemeran atau actor terjadinya pelanggaran Hak Asasi Manusia.

Jika di kaitkan Pelanggaran hak asasi manusia di atas maka kaum minoritas atau kelompok muslim mendapat suatu tindakan yang kurang menyenangkan dari penguasa sehingga adanya pemenuhan unsur penyalahgunaan kekuasaan oleh penguasa atau sering di sebut Pelanggaran hak asasi manusia secara aktif dimana india berperan dalam mengeluarkan undang-undang kewarganegaraan tersebut. India sebagai negara yang harusnya memeperhatikan hak asasi manusia secara utuh karna meratifikasi konvensi mengenai hak asasi manusia namun ketika penerbitan Undang-undang Kewarganegaraan ini muncul menjadi permasalahan baru mengenai hak asasi manusia sehingga negara yang mestinya melindungi ini justru sebaliknya dimana penguasa di india kurang pedulinya terutama mengenai keagaaman terutama pada kaum muslim yang beragama islam .

\section{Kesimpulan}

Hak asasi manusia sering disebut juga suatu hak yang tidak dapat di ganggugugat oleh siapapun keberadaanya serta perlindungan terhadap orang/kelompok orang/ masyarakat/warga negara di suatu negarapun di jamin perlindungannya. Konvensi internasional mengenai hak asasi manusia sebenarnya memipikirkan tentang hak-hak individu untuk bebas memilih sesuatu yang seseorang percaya termasuk masalosah agama , permaslahan di india memperlihakan bahwa adanya suatu diskriminasi pada kelompok minoritas yang hanya $12 \%$ dari suatu negara sehingga rentan untuk di diskriminasi oleh beberapa kelompok. Permasalahan ini terjadi dikarnakan penerbitan undang-undang kewarganegaraan di india yang hany mencantumkan Hindu, Sikh, Budha, Jain, Parsi atau Komunitas Kristen saja sedangkan orang muslim yang memeluk agama 
islam di india mendapat diskriminasi melalui kebijakn politik yang di hasilkan melalui undang-undang yang terbit.

\section{Saran}

Permasalahan kaum muslim di india memakan korban yang cukup banyak walaupun hal itu permasalahan konflik antara kelompok agama namun hal ini terjadi dikarnakan terbitnya Undangundang kewarganegaraan india yang tidak memasukan agama islam dan mendiskriminasi umat muslim yang memeluk agama islam seharusnya india sebagai negara yang meratifikasi beberapa konvensi hak asasi manusia mengimplementasikan dan melindungi masyarakat bukan memprovokasi dengan pengeluaran undang-undang yang membuat kontroversial hal ini walaupun pembuatan produk Undang-undang suatu negara adalah hak suatu negara menerapkan hukum negara tersebut namun seharus negara tersebut tidak membela ataupun melindungi beberapa kelompok saja namun semuanya.

\section{DAFTAR PUSTAKA}

F. (2009). MEMAHAMI DISKRIMINASI. The Indonesian Legal Resource Center (ILRC) . Jakarta.

. M. (2015). Persoalan Dilematis Muslim Minoritas Dan Solusinya. Adab Dan Humaniora Iain Salatiga, 10(1). Deklarasi Universal Hak Asasi Manusia.

Konvensi Internasional Tentang Hak Sipil Dan Politik.

Riyadi, E. (2018). Hukum Asasi manusia: Prespektig internasional, regional dan nasional. PT. Raja Garfindo persada. Depok.

Siddiqui, D. (2020). Korban Tewas Kerusuhan Di India Capai 42 Orang, Kekerasan Dipicu UU Kewarganegaraan

Kontroversial. 2 Maret 2020. https://aceh.tribunnews.com/202 0/03/02/Korban-Tewas-

Kerusuhan-Di-India-Capai-42-

Orang-Kekerasan-Dipicu-Uu-

Kewarganegaraan-

Kontroversial?Page

Sinintya Mangkuto, W. (2019). UU 
Kewarganegaraan Anti-Muslim India, Mengapa Memicu Protes? 24 December 2019.

Suci Agiesta, F. (2020). Cerita Lengkap UU Kewarganegaraan India Diskriminasi ke Muslim Berujung Korban Nyawa. 27

Februari 2020.

https://www.merdeka.com/duni a/cerita-lengkap-uukewarganegaraan-indiadiskriminasi-ke-muslimberujung-korban-nyawa.html

Sujatmoko, A. (2015). Hukum HAM dan hukum humanitair. PT. Raja Garfindo persada. Jakarta. F. (2009). MEMAHAMI DISKRIMINASI. The Indonesian Legal Resource Center (ILRC) . Jakarta.

. M. (2015). Persoalan Dilematis Muslim Minoritas Dan Solusinya. Adab Dan Humaniora Iain Salatiga, 10(1).

Deklarasi Universal Hak Asasi Manusia.

Konvensi Internasional Tentang Hak Sipil Dan Politik.

Riyadi, E. (2018). Hukum Asasi manusia: Prespektig internasional, regional dan nasional. PT. Raja Garfindo persada. Depok.

Siddiqui, D. (2020). Korban Tewas Kerusuhan Di India Capai 42 Orang, Kekerasan Dipicu UU Kewarganegaraan

Kontroversial. 2 Maret 2020. https://aceh.tribunnews.com/202 0/03/02/Korban-Tewas-

Kerusuhan-Di-India-Capai-42-

Orang-Kekerasan-Dipicu-Uu-

Kewarganegaraan-

Kontroversial?Page

Sinintya Mangkuto, W. (2019). UU Kewarganegaraan Anti-Muslim India, Mengapa Memicu Protes? 24 December 2019.

Suci Agiesta, F. (2020). Cerita Lengkap UU Kewarganegaraan India Diskriminasi ke Muslim Berujung Korban Nyawa. 27 Februari 2020. https://www.merdeka.com/duni a/cerita-lengkap-uukewarganegaraan-indiadiskriminasi-ke-muslimberujung-korban-nyawa.html Sujatmoko, A. (2015). Hukum HAM dan hukum humanitair. PT. Raja Garfindo persada. Jakarta. 
